\title{
Notes and Documents
}

\section{THE FAMILY OF WILLIAII THE CONQUEROR AND THE CHURCH OF CHARTRES.}

Arrose the French churches which were enriched by Anglo-Norman gifts Chartres may claim an exceptional interest, since its bishop, the great canonist St. Ivo, mas induced to prepare the way for the English concordat of 1105 partly by his personal relations to the Conqueror's daughter Adela, countess of Chartres. The 'Necrologium' 'of Chartres Cathedral was begun about 1027 and continued, at five different times, until 1137. King Cnut is not mentioned ; if, therefore, his gift to Chartres was forgotten in 1035, it probably belongs, as well as bishop Fulbert's grateful letter to him, to his early years. ${ }^{2}$ The Conqueror's death is entered

5 Idus Sept.: Guillelmus rex Anglorum et dux Normannorum, qui huic ecclesie multa bona fecit.

His queen ${ }^{3}$ is spolsen of in the note-

2 Kal. Nov.: Obiit Matildis Anglorum regina, que hanc ecclesiam dilectionis privilegio amplectens et venerans, plumbeo tegmine decoravit et preter alia multa beneficia, casulam ei deauratam et xl libras nummorum ad usus fratrum donavit.

We find one of their daughters entered by a scribe of about 1070-

Adeliza 4 filia regis Anglorum, pro cuius anima pater eius rex inter alia clara et regia beneficia qua fecit huic ecclesiae iussit fieri campanarium quod est super aecclesiam preciosum et bonum.

Another daughter is rightly entered-

8 Idus Mart. : Obiit Adela comitissa [1137].

The same scribe adds-.

Obiit venerabilis et eloquens vir Henricus Dei gratia Anglorum rex.

'Edited by R. Merlet and A. Clerval, Cn Manuscrit Claavtrain clu XI' s.; Fulbert de Chartrcs (Soc. Archéol. d' Eure-et-Loir), Chartres, 1593, p. 149 . It had been printed before, in the Cartulaire de N. Dame de Chartres, vol. iii. (Chartres 1865).

" So Steenstrup, Normannernc, iii. 338, supposed on other grounds.

a Not Matilda II, the wife of Henry I, ' + 1118.' Matilda I died 3 Nov. 1033 Freeman, Norman Conq. iv. 65̃1, 2nd ed., 1876).

+ She had once been betrothed to Harold (Freeman, iii. 668, 2nd ed., 187:). 
Henry $I^{5}$ had died 1 Dec. If his death is mentioned under this wrong date, the reason must have been that the writer recalled brother and sister together, possibly in consequence of their intimacy. Henry's brother-in-law Eadgar ${ }^{6}$ died

7 Id. Jan.: Edwardus rex Scothiae, vir honestissimus et Dei servitio devotissimus.

These short notes confirm what we know of William's liberality to churches, Henry's readiness in speech, and the religious character of the son of St. Nargaret.

F. LiEbERMANA.

\section{THE PARLIAMENT OF 1264.}

IN July 1896 I printed in this Review a fragmentary account of the battle of Lewes which I found on the flyleaf of a canon-law manuscript in the royal collection. A source very similar provides me with another small contribution to history, belonging, as it happens, to the very same year. The Royal MS. 8. D. iii., containing miscellaneous treatises, chiefly on canon law, belonged to Ramsey Abbey. Blank leaves between the tracts were rather plentiful, and naturally became a receptacle for miscellaneous notes written by the monks. The particular entries in question are copies of five documents, written in a hand contemporary (so far as may be judged) with the events. The first three are well enough lnown, being the letters ${ }^{1}$ interchanged between the two parties at Fletching and Lerres on $12 \mathrm{May}$, two days before the battle. The other two documents I believe to be hitherto unnoticed, and have therefore transcribed them below. The substance of the first is a simple confirmation of a royal charter which appears on the patent roll (and in 'Foedera,' i. 444) under date 23 June 1264. The interest of it lies first in the fact of such confirmation, and secondly, and to a greater degree, in its wording, upon which, in the case of the first proceedings under a new constitutional scheme, it seems permissible to lay rather more stress than one would normally be justified in doing. Of this constitution of 1264 the late bishop of Oxford wrote: ${ }^{2}$ 'It is observable that the linights of the shire are not recognised as having a voice in the choice of either electors or counsellors.' This may be strictly true, though the document upon which he is commenting (' Select Charters,' p. 412) does mention the communitas regri, the precise meaning of which it is not very easy to define; but in the confirmation now in question, unless the words come from a monk's political imagination, we have

s On his hospital for lepers at Chartres see Freeman, v. 844.

- Not 'Édouard,' as the editors say.

'Foedera, i. 440 ; als 3 in N. Trivet and Rishanges: There is another cops on nother Ramsey MS. flyleaf, 5. F. xv.

2 Const. History. ii. 98 . 